\title{
NATION: A METAMORPHOSIS
}

\section{Prof. Rajkumar S.Nagar}

1. Concept of the Nation

2. Community, State, Nation and Country

3. Kingdom and Country

4. Nation in terms of Feudal, Capitalism and Socialist Eco-Socio-Political system.

5. In the light of "Vasudheva Kutumbkam" and "Proletariat Internationalism".

6. Liberal and Fascist views.

\section{Concept of the Nation}

"The state occurs in a specific historic stage with inbuilt contradictions and conflicts.“

'Origin of the Family, Private Property, and the State' Friedrich Engels (Eng. Tr by Alick West published in 1942)

The term nation is ostensibly one of most easily misunderstood, and loosely used term. One of the most prevalent naïve misconception about it is related to its origin. Its roots are considered to be parallel to the evolution of human being. But, it is not that old a phenomenon. Comparatively, it is a very new thing. Scientifically, its roots goes back to the time of the industrial revolution. It is not only a new term but a modern concept of the state. After the French revolution, the socio-eco-political conflict transformed radically. The class conflict, the ownership of the means of the production changed drastically, hence, the whole super structure also transformed. The biggest transformation was that of from the feudal set of society to capitalist set of the society. And unfailingly this transformation hugely got reflected in the nature of the state, namely from kingdom (monarchy) to nation.

State is political entity while the nation is more concerned with cultural aspect of the collective mileu. State is more related to the geographical and political dimension, while nation is more concerned with cultural, religious and living style of the people.

Monarchy represented an old bunch of values based on the agrarian socio-economic set up. It used to control, in certain parts of world the system of slavery, exploitation of artisans and the landless farm workers or small farmers. With the emergence of industry and expansion of trade, new class relations and conflicts evolved. The new unresolved class conflicts paved way to a new political set up, i.e. state. It was the manifestation of the emerging dominant bourgeoisie class with new set of values namely 'liberty, equality and fraternity'. The old values, social structure, religious beliefs, family ties and class relations based on the ownership of means of the production etc. were the foundation of the newly emergent state. The state, with all its apparatus, try to pacify the intensity of the class conflicts or maintain the 'status quo'. Here status quo means to help the dominant class to carry on the exploitation. 


\section{Community, State, Nation and Country}

Community was the most naive form of nation.

During the primitive phase human beings used to live in the jungles. For the sake of safety and survival they were bound to live in groups. They had to live together in order to live, fight against the natural odds. Survival was the key. And, during primitive phase only physical strength was a boon. Naturally the joint strength of the group was bigger than the single person/s. Hence, the experience taught the great lesson to the human being. Thus, the community came into the existence. Bigger the community safer it was. These groups- communities- not only helped to survival of the individuals, fight against the natural forces and wild animal but after a period they fought among themselves for ownership of the resources i.e. jungle, land and water etc. These fights, conflicts, or on larger scale wars, led to the building of the king and kingdom. It was a radical transformation. From community to kingdom. Hence, the feudal form of 'state' i.e. kingdom came into existence.

Community life helped to form common ways of living, expression, eating, wearing etc. From roaming way of living to stability came into practice. Hence, formation of houses, farming, use of animals. Now the strong accommodation was needed. Houses, forts and strong walls for the purpose of safety became necessity of the safe life. Strong warriors took the reins of the life in their hands.

This was the initial phase of the formation of the kingdom. It was not the equivalent to the nation.

From the very inception the kingdom was a set up or tool in the hands of powerful.

\section{Kingdom and Country}

The kings form their kingdoms as per their strength. The more powerful the army bigger the kingdom. The territory of the kingdom used to depend on the skill, efficiency and the strength of the armory. Hence, the map of the kingdom was not determined by the religion, language, cultural ethos, life style etc. The modern concept of the country is not older than 350 years. After the crumbling of the feudal system and emergence of industrialization, the ideals of the French revolution, liberty, equality and fraternity paves way to the emerging manifestation of the new concept of the country in which the interests of new bourgeois class dominated.

The emergence of 'country' was the reflection of the changing relations of the means of production. The new pattern of the changing class conflicts of the bourgeois and working class gets manifestation in the formation of "country.

\section{Nation in terms of Feudal, Capitalism and Socialist Eco-Socio-Political system.}

The entity of the country metamorphosed subtly from Feudal to Capitalist and from Capitalist to Socialist 'country'. In these different forms of the 'country' the interests of the ruling class dominance gets reflected. 
Nation (Nation-State) always has been used as a powerful apparatus by the ruling class to dominate the society, natural resources, and the means of the production.

The bourgeoisie as a ruling class emerged after the Industrial Revolution and it crushed the old value system along with the old vested interests of the aristocratic- noble- class.

It was overthrown by the working class or the toiling masses during the Socialist Revolution. A new kind of socialist state was established in the USSR in 1917. First time in the history of mankind 'have nots' took the reins of the state in its hands. The powerful class was replaced by the proletariats and all the means of the production were under taken by the new owners i.e. working class and the farmers.

\section{In the light of "Vasudheva Kutumbkam" and "Proletariat Internationalism".}

For us four Vedas and eighteen Upanishads are considered accepted referent to all the fields of knowledge. In India, the high values of the well-known 'Vasudheva Kutumbakam' encompass deep and wide world view. The spirit of the 'Vasudheva Kutumbakam' has always been respected and show the liberal and all-embracing way of living. According to this, the whole world is considered a family and we are the members of this larger family. The very essence of this negates the inherent antagonistic elements of the nation. The very existence of the nation is based on differences or antagonism. The ideal of 'Vasudheva Kutumbakam' and the concept of the nation can not go hand in hand. One is vast while another sectarian. All the human beings are considered one irrespective of the class, creed and the colour in the former. While the later based on superiority of the self and dislike for the others.

On the other hand the concept of 'Proletariat Internationalism', across the countries all the proletariats - exploited class or 'have not'- are considered one and envisage the classless and exploitation less, equal and just society in which the narrow borders of the country would dissolve. In this view, all the exploited classes would join their hands and they took over the reins of the states. In this phase, the state apparatus, the tool of the exploitation would crumble down and the stateless system of governance would emerge. This form of the governance would not mean to suppress any class of the society. Hence, it would lead to a classless, oppression less, exploitation less, equal society.

\section{Liberal and Fascist views.}

The liberal view of the country try to accommodate the interests of all the classes in harmonious manner. They imagine that all the conflicting classes may co-exist without conflicts. Haves and have nots, the followers of the different religions and sects, different castes in the caste ridden Indian society, people with different life styles, cultures etc. They, ideally, imagine all of them can live together harmoniously.

While, fascist view believes that the religion of the majority or dominant group must rule the minority or the lower strata based on caste, creed or any discriminating entity.

Hence, their concept the nation is sectarian and based on the theory of superiority a particular dominating / majority group, like superiority of the pure Aryan Blood in Nazi German of the Hitler.

Nowadays, this concept of the sectarian 'nation' is getting momentum. Be it USA or India. The very essence of this notion is based on discrimination based on the superiority of religion, blood, colour of the skin, cultural ethos etc. The fascist or the chauvinist - 
extreme- view is entirely based on the antagonism or hatred towards the minority group, be it religious, sect, nationalistic.

\section{Conclusion}

Nation is not only a geographical entity. Its existence becomes meaningful with its inhabitants.

The failures of addressing the key issues and the aspiration of the majority of the people have led them to turn towards the sectarian views. Ultimately, the basic needs of would have the upper hand and hollow values would vanish or would be cut to their size. A healthy classless society based on equality and justice would emerge after all turmoil.

Ultimately, the nation- state is also a transitional phase in the long history of the human kind.

And now, in conclusion, Morgan's judgment of civilization:

"Since the advent of civilization, the outgrowth of property has been so immense, its formsso diversified, its uses so expanding and its management so intelligent in the interests of its owners, that it has become, on the part of the people, an unmanageable power. The human mind stands bewildered in the presence of its own creation. The time will come, nevertheless, when human intelligence will rise to the mastery over property, and define the relations of the state to the property it protects, as well as the obligations and the limits of the rights of its owners. The interests of society are paramount to individual interests, and the two must be brought into just and harmonious relations. A mere property career is not the final destiny of mankind, if progress is to be the law of the future as it has been of the past. The time which has passed away since civilization began is but a fragment of the past duration of man's existence; and but a fragment of the ages yet to come. The dissolution of society bids fair to become the termination of a career of which property is the end and aim; because such a career contains the elements of selfdestruction. Democracy in government, brotherhood in society, equality in rights and privileges, and universal education, foreshadow the next higher plane of society to which experience, intelligence and knowledge are steadily tending. It will be a revival, in a higher form, of the liberty, equality and fraternity of the ancient gentes."

[Ancient Society, by Lewis H. Morgan, London, Macmillan \& Co., 1877, p. 562]

\section{Prof. Rajkumar S.Nagar I/C Principal Arts \& Commerce College, Kheda}

